\title{
Differences in Growth and
} Calcification Rates in the Reef-Building Coral Porites lobata: The Implications of Morphotype and Gender on Coral Growth

\section{OPEN ACCESS}

Edited by:

Edwin A. Hernández-Delgado, University of Puerto Rico School of Law, Puerto Rico

Reviewed by:

Aldo Cróquer,

Simón Bolivar University, Venezuela Jarosław Stolarski,

Polish Academy of Sciences, Poland

*Correspondence: Alma P. Rodríguez-Troncoso pao.rodriguezt@gmail.com

Specialty section: This article was submitted to

Coral Reef Research,

a section of the journal

Frontiers in Marine Science

Received: 23 May 2016 Accepted: 05 September 2016

Published: 26 September 2016

Citation

Tortolero-Langarica JJA, Cupul-Magaña AL,

Carricart-Ganivet JP, Mayfield $A B$ and Rodríguez-Troncoso AP (2016)

Differences in Growth and Calcification Rates in the Reef-Building Coral Porites lobata: The Implications of Morphotype and Gender on Coral Growth. Front. Mar. Sci. 3:179. doi: 10.3389/fmars.2016.00179

\author{
José de Jesús A. Tortolero-Langarica ${ }^{1,2}$, Amilcar L. Cupul-Magaña ${ }^{2}$, \\ Juan. P. Carricart-Ganivet ${ }^{3}$, Anderson B. Mayfield ${ }^{4}$ and Alma P. Rodríguez-Troncoso ${ }^{2 *}$ \\ ${ }^{1}$ Instituto Tecnológico de Bahía de Banderas, Tecnológico Nacional de México, Bahía de Banderas, Mexico, ${ }^{2}$ Laboratorio de \\ Ecología Marina, Centro de Investigaciones Costeras, Centro Universitario de la Costa, Universidad de Guadalajara, Puerto \\ Vallarta, Mexico, ${ }^{3}$ Unidad Académica de Sistemas Arrecifales, Instituto de Ciencias del Mar y Limnología, Universidad \\ Nacional Autónoma de México, Cancún, Mexico, ${ }^{4}$ Living Oceans Foundation, Annapolis, MD, USA
}

Corals display different growth forms as an adaptive response to both local and global environmental conditions. Despite the importance of morphologic variability on corals, growth and calcification rates of different coral morphotypes have been poorly recorded in the Eastern Pacific. The purpose of this study was to compare annual extension rate $\left(\mathrm{cm} \mathrm{yr}^{-1}\right)$, skeletal density $\left(\mathrm{g} \mathrm{cm}^{-3}\right)$, calcification rate $\left(\mathrm{g} \mathrm{cm}^{-2} \mathrm{yr}^{-1}\right)$, and tissue thickness $(\mathrm{mm})$ of males and females colonies in three different morphotypes of the common reef-building coral Porites lobata; columnar, massive, and free-living (corallith) forms. The results show significant differences in all four-growth parameters between morphotypes over a 6-year interval, and also differences between males and females in most morphotypes. Massive colonies presented 15-33\% faster annual rates compared with columnar and free-living. Male colonies showed $30-40 \%$ faster annual rates than females for both columnar and corallith morphologies. These data exhibit the extensive plasticity of this species and highlight the fact that each morphotype $\times$ gender group produced a different physiological response to environmental conditions. Therefore, these information reveal that $P$. lobata from the Eastern Tropical Pacific develops different morphologies to allow it to maintain coral species population, characteristics that enhance the species possibility to further its distribution across the reef-framework.

Keywords: coral morphology, gender growth rates, Eastern Tropical Pacific, massive corals, coral calcification

\section{INTRODUCTION}

Morpho-plasticity in colony structure is an adaptive strategy upon which some coral species rely to take advantage of changes in their environment (Foster, 1979; Muko et al., 2000; Smith et al., 2007; Todd, 2008; Forsman et al., 2009). Hermatypic corals can adopt branching, massive, encrusting, columnar, laminar, foliaceous, nodular, and free-living (corallith) forms (Veron, 2000). However, morphologic variation may be present within not only a single species, but even within a single colony; such phenomena are typically in response to local environmental conditions, which 
influence coral growth and led to changes in skeletal architectures (Hughes, 1987; Lough and Barnes, 2000; Lough and Cooper, 2011). In general, the development of distinct morphotypes may be influenced by several exogenous factors, such as substrata type, depth, competition, space and light availability, bioturbation, and water dynamics (Glynn, 1974; Foster, 1979; Hughes, 1987; Van Veghel et al., 1996; D'Croz et al., 2001; Grigg, 2006; Smith et al., 2007; Tortolero-Langarica et al., 2016), as well as endogenous factors, such as the Symbiodinium assemblage and genetic variations (Van Veghel et al., 1996; D’Croz et al., 2001; Grigg, 2006; Smith et al., 2007; Todd, 2008; Forsman et al., 2009; Paz-García et al., 2009; Barshis et al., 2010; Boulay et al., 2012). The influence of all these factors may promote differences in the metabolic pathways that each species invest their energy resources, resulting in different skeletal characteristics in order to guarantee their continual growth and survival (Veron, 2000; Smith et al., 2007). Different colony forms not only benefit the species survival, but also contribute to the reef structure and complexity; such which increases in rugosity are associated with increased the biodiversity (Spalding et al., 2001; Alvarez-Filip et al., 2009).

One of the most abundant reef-building coral genera of the tropical Pacific Ocean is Porites, which normally adopts a massive growth form (Guzmán and Cortés, 1993; Glynn et al., 1994; Lough et al., 1999; Lough, 2008; Lough and Cooper, 2011). Poritid corals can be present in different morphotypes in the same reef area (Smith et al., 2007; Paz-García et al., 2009; López-Pérez, 2013). In addition, the nature of coral accretion in massive species is well understood and allows recognition of specific skeletal features, such as high and low density bands, over time (Lough and Barnes, 2000). Such banding patterns are typically assessed in conjunction with other growth parameters such as the skeletal extension rate (linear growth, in $\left.\mathrm{cm} \mathrm{yr}^{-1}\right)$, skeletal density $\left(\mathrm{CaCO}_{3}\right.$ bulk mass, in $\mathrm{g}$ $\left.\mathrm{cm}^{-3}\right)$, calcification rate $\left(\mathrm{g} \mathrm{cm}^{-2} \mathrm{yr}^{-1}\right)$, and tissue thickness (depth of live tissue, in mm) (Knutson et al., 1972; Lough and Barnes, 2000; Carricart-Ganivet and Barnes, 2007). The sex of coral can also affect its growth and timing of densityband formation, due males and females invest in different proportions the energy available for physiological processes such as reproduction and calcification (Harrison, 2011; CarricartGanivet et al., 2013). In consequence, genders may present different annual growth parameters between them (Cabral-Tena et al., 2013). Therefore, the coral's genders may affect the interpretation of the environmental proxies bound within the skeleton (Carricart-Ganivet et al., 2013).

In the Eastern tropical Pacific (ETP), Porites lobata Dana 1846 , is an important component of the structure of coral reef communities (Guzmán and Cortés, 1989; Glynn, 1994; Glynn and Ault, 2000). Despite the importance of morphologic and growth variability in the reef structure, limited studies have been performed on massive corals (Graus and MacIntyre, 1982; Tomascik, 1990; Van Veghel and Bosscher, 1995; Smith et al., 2007). These include the reported by Norzagaray-López et al. (2014) who found growth differences between columnar and encrusting colonies, nevertheless it is important to highlight that these differences were possibly biased by the effect of the gender and latitudinal gradients variations. To date, a comparison of the growth of different morphotypes including the gender effect in Poritid corals has not been undertaken, though it seems reasonable to speculate that columnar, massive and free-living forms may calcify at different rates in each specific gender. We hypothesized that columnar and massive forms attached to the substrata have major extension and calcification rates compared with mobile free-living colonies and higher rates in male colonies, due to their different strategies to invest calcification resources. In order to test this hypothesis, extension rate, skeletal density and calcification rate were assessed using optical densitometry on three different morphotypes and gender of $P$. lobata. In addition, tissue thickness and time of formation of both high and low density-bands among the morphotypes and genders were documented and compared.

\section{MATERIALS AND METHODS Study Area and Coral Sampling}

$P$. lobata morphotypes were collected in Isla Isabel National Park (IINP) (permission number: DGOPA.04552.040711.1798), located at $25 \mathrm{~km}$ offshore of the Nayarit coast, in the central Mexican Pacific $\left(20^{\circ} 40^{\prime} 35^{\prime \prime}-20^{\circ} 41^{\prime} 45^{\prime \prime} \mathrm{N}\right.$, $105^{\circ} 33^{\prime} 30^{\prime \prime}-105^{\circ} 38^{\prime} 10^{\prime \prime} \mathrm{W}$; Figure 1). The reef area is composed of fringing coral reef patches around the island, where branched corals Pocillopora species and columnar massive Porites species dominate and share the principal coral reef area between 2 and $6 \mathrm{~m}$ depth. Other massive forms such as massive and coralliths are distributed irregularly on flat rocky and calcareous bottom at 4-8 m (CONANP, 2007). The sea surface temperature (SST) of the zone is influenced mainly by two inter-annual transitional ocean currents, the California Current (CC) brings SST of $18-21^{\circ} \mathrm{C}$ from January to March (Shea et al., 1992; Kessler, 2006; Pennington et al., 2006; Pantoja et al., 2012), and the Mexican Costal Current (MCC) is characterized by SST of $27-30^{\circ} \mathrm{C}$ between July and November (da Silva et al., 1994; Kessler, 2006; Pennington et al., 2006; Palacios-Hernández et al., 2010; Pantoja et al., 2012). Several authors have reported periodical temperature anomalies driven by El Niño-Southern Oscillation events with both ElNiño $\left(+3^{\circ} \mathrm{C}\right.$; SST) and LaNiña $\left(-4^{\circ} \mathrm{C}\right.$; SST) phases which has caused massive coral bleaching and mortalities episodes (Glynn, 2000; Carriquiry et al., 2001; Reyes-Bonilla et al., 2002; Fiedler and Talley, 2006; Kessler, 2006; Wang and Fiedler, 2006; Cupul-Magaña and Calderón-Aguilera, 2008).

\section{Coral Growth Measurements}

Sampling was conducted in October 2013. Using a hammer and chisel, a total of $11 \mathrm{P}$. lobata colonies $(70 \mathrm{~cm}$ on average) of three different morphologies were collected in the same area at 3-5 m: massive $(n=3)$, columnar $(n=4)$, and free-living coralliths $(n=4)$ (Figure 2). In the laboratory, in order to eliminate organic material, all samples were washed with fresh water, dried using compressed air and then placed in a conventional oven at $75^{\circ} \mathrm{C}$ for $10 \mathrm{~h}$. Coral samples were sectioned from the main growth axis into slices of $7-10 \mathrm{~mm}$ thickness, using a tipped diamond saw blade (Qep). Coral slices were X-radiographed using a General Electric X-ray machine (GE Hungay Rt. Medical 


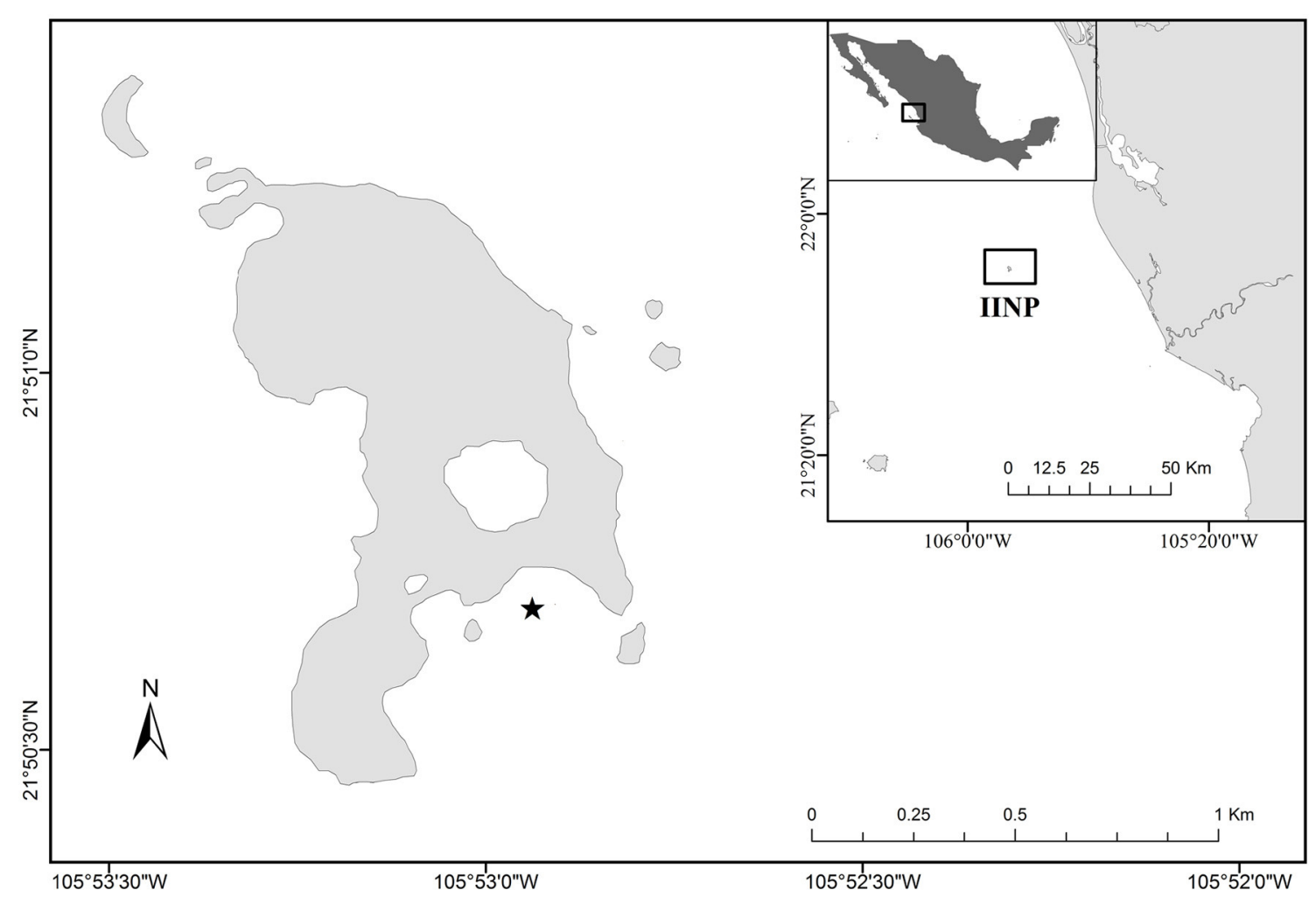

FIGURE 1 | Study area, Isla Isabel National Park (IINP). Black star denote the site of collection.

Systems), with the exposure set to $70 \mathrm{kv}$ for $20 \mathrm{mAs}$ at a 2 - $\mathrm{m}$ distance between the X-ray source and the coral samples (Figure 2).

Radiographic images were corrected using the method described by Duprey et al. (2012) to eliminate the irradiation bias (e.g., "heel effect" and "square law"). Corrected images were analyzed using ImageJ (ver. 1.46, http://rsb.info.nih.gov/ij/) to obtain density values $\left(\mathrm{g} \mathrm{cm}^{-3}\right)$ though perpendicular tracks $(0.20$ $\mathrm{mm}$ ) along the highest growth axis of each colony, using the method described by Carricart-Ganivet and Barnes (2007). Data of linear extension rate was measured between the distance of adjacent density minima peaks, which represent a theoretical annual periods $\left(\mathrm{mm} \mathrm{yr}^{-1}\right)$, and calcification rate $\left(\mathrm{g} \mathrm{cm}^{-2} \mathrm{yr}^{-1}\right)$ were calculated as the product of skeletal density and extension rate (Lough and Barnes, 2000; Carricart-Ganivet and Barnes, 2007; Lough and Cooper, 2011).

Tissue thickness $(\mathrm{mm})$ was measured with a digital caliper (Mitutoyo, $0.001 \mathrm{~mm}$ precision) from the fringe to the deepest mark of live tissue along each colony. In addition, tissue thickness was also used to determine the timing of high density (HD) band depositation, which can be readily calculated due to the well understand impact of depth tissue on the apparent density band formation on corals with porous skeletons, such as Porites species (Barnes and Lough, 1993). The differences between real and apparent timing of density-band formation was estimated using the method described by Carricart-Ganivet et al. (2013), and indicated as the apparent time differences (ATD).

\section{Coral Sex Identification}

A small fragment of each colony was fixed in $10 \%$ formalin in seawater and stored at room temperature. Each fragment was individually decalcified with $10 \% \mathrm{HCl}$ mixed with a buffer $(0.7 \mathrm{~g}$ EDTA, $0.14 \mathrm{~g}$ sodium tartrate, and 0.008 potassium sodium tetrahydrate), and the tissue obtained was rinsed with running fresh water and preserved in $70 \%$ ethanol. Afterwards, tissues were dehydrated using a 10-step Histoquinet Leica and embedded in Paraplast X-tra. Sections of $8 \mu \mathrm{m}$ thickness were obtained with a semi-automatic Leica microtome. Preparations were stained using Masson's trichrome protocol (Humanson, 1967). Slides were analyzed using a compound microscope (LABO JAZ-ANZ). Gamete presence and gender identification were determined as described by Rodríguez-Troncoso et al. (2011).

\section{Data Analysis}

Mean average values of all coral growth parameters ( \pm standard deviation) were calculated for each morphotype and gender. After evaluation of normality and homoscedasticity $(P<0.05)$, non-parametric analysis of variance on ranks (i.e., KruskallWallis test) were used to compare levels of growth parameters between morphotypes and General Linear Model two-way ANOVA with fixed- effects was used in order to assess the effect of morphology, gender and their interaction on coral growth. Pearson's product moment tests were used to determine the significance of correlation between extension rate, density and 
calcification rate. All statistical analyses were conducted with Sigma Plot (ver. 11, SPSS) and Statistical (ver. 8, Stats) software, and an alpha level of 0.05 was set a priori.

\section{RESULTS}

Coral parameters resulted from 80 pairs of density bands over a 6 years interval. P. lobata present a mean extension rate of $0.57 \pm 0.03 \mathrm{~cm} \mathrm{yr}^{-1}$, a mean density of $1.17 \pm 0.02 \mathrm{~g} \mathrm{~cm}^{-3}$, and a mean calcification rate of $0.65 \pm 0.03 \mathrm{~g} \mathrm{~cm}^{-2} \mathrm{yr}^{-1}$. At temporal level growth parameters does not showed differences
$(P>0.05)$ over the 6 years analyzed (Table 1). However, growth metrics were significant different between coralliths, massive and columnar forms: in extension rate $(H=13.523, P=0.001)$, skeletal density $(H=33.026, P<0.001)$, and calcification rate $(H=6.444, P=0.040$; Figure 3$)$. Columnar colonies showed an average of 33 and 15\% lower rates in extension and calcification among the morphotypes. The gender was identified only for columnar and coralliths forms, massive colonies not showed evidence of sex gametes. Analysis of growth parameters between males and females colonies resulted in similar growth parameters when gender data pooled (Table 2). However, this was statistical different using the effect of morphotype and gender
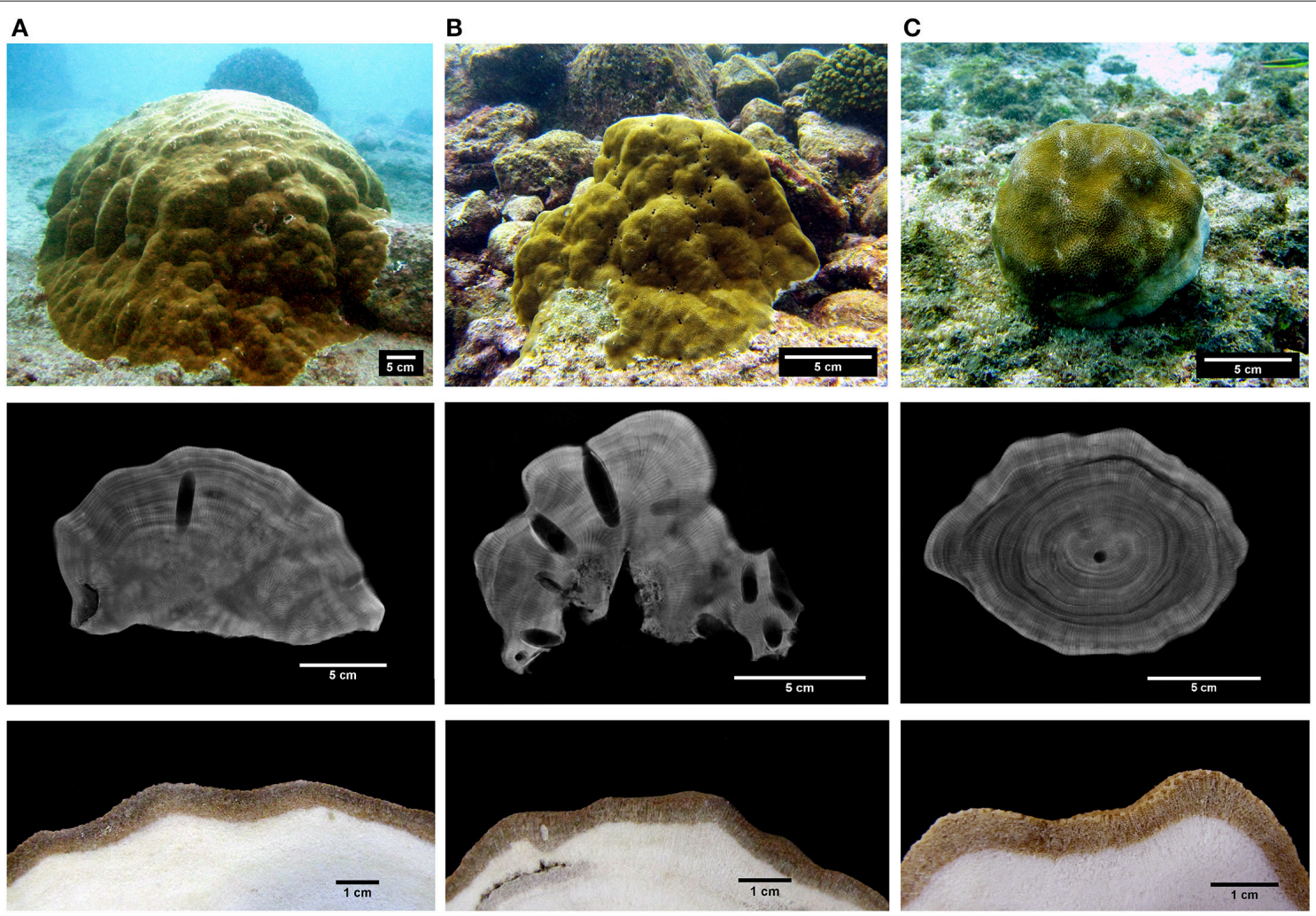

FIGURE 2 | Different morphotypes of Porites lobata in situ, under X-radiography and photograhps of coral slices displaying tissue thickness. (A) Massive, (B) Columnar, and (C) Corallith (free-living).

TABLE 1 | Mean annual growth ( $\pm \mathrm{SD}$ ) of $P$. lobata morphotypes: extension rate, skeletal density, and calcification rate, (n) indicate the number of pair of growth bands evaluated by year.

\begin{tabular}{|c|c|c|c|c|c|c|c|c|c|}
\hline Year & \multicolumn{3}{|c|}{ Corallith } & \multicolumn{3}{|c|}{ Massive } & \multicolumn{3}{|c|}{ Columnar } \\
\hline 2008 & $1.11 \pm 0.14$ & $0.65 \pm 0.24$ (4) & $0.71 \pm 0.22(4)$ & $1.18 \pm 0.03(3)$ & $0.65 \pm 0.23$ (3) & $0.77 \pm 0.28$ & $1.07(1)$ & $0.45(1)$ & $0.49(1)$ \\
\hline 2009 & $1.05 \pm 0.14$ & $0.60 \pm 0.17(4)$ & $0.61 \pm 0.13(4)$ & $1.22 \pm 0.04$ & $0.57 \pm 0.22(3)$ & $0.70 \pm 0.26(3)$ & $1.22 \pm 0.13(3)$ & $0.76 \pm 0.55(3)$ & $0.92 \pm 0.6$ \\
\hline 2010 & $0.98 \pm 0.07(4)$ & $0.70 \pm 0.20$ & $0.68 \pm 0.18(4)$ & $1.22 \pm 0.05$ & $0.64 \pm 0.36$ (3) & $0.77 \pm 0.41$ & $1.25 \pm 0.16(3)$ & $0.70 \pm 0.36$ & $0.85 \pm 0.44$ \\
\hline 2013 & $1.19 \pm 0.13(4)$ & $0.71 \pm 0.06$ & $0.84 \pm 0.09$ (4) & $1.32 \pm 0.03(3)$ & $0.33 \pm 0.06(3)$ & $0.44 \pm 0.08(3)$ & $1.38 \pm 0.20(4)$ & $0.35 \pm 0.06(4)$ & $0.48 \pm 0.11$ \\
\hline
\end{tabular}




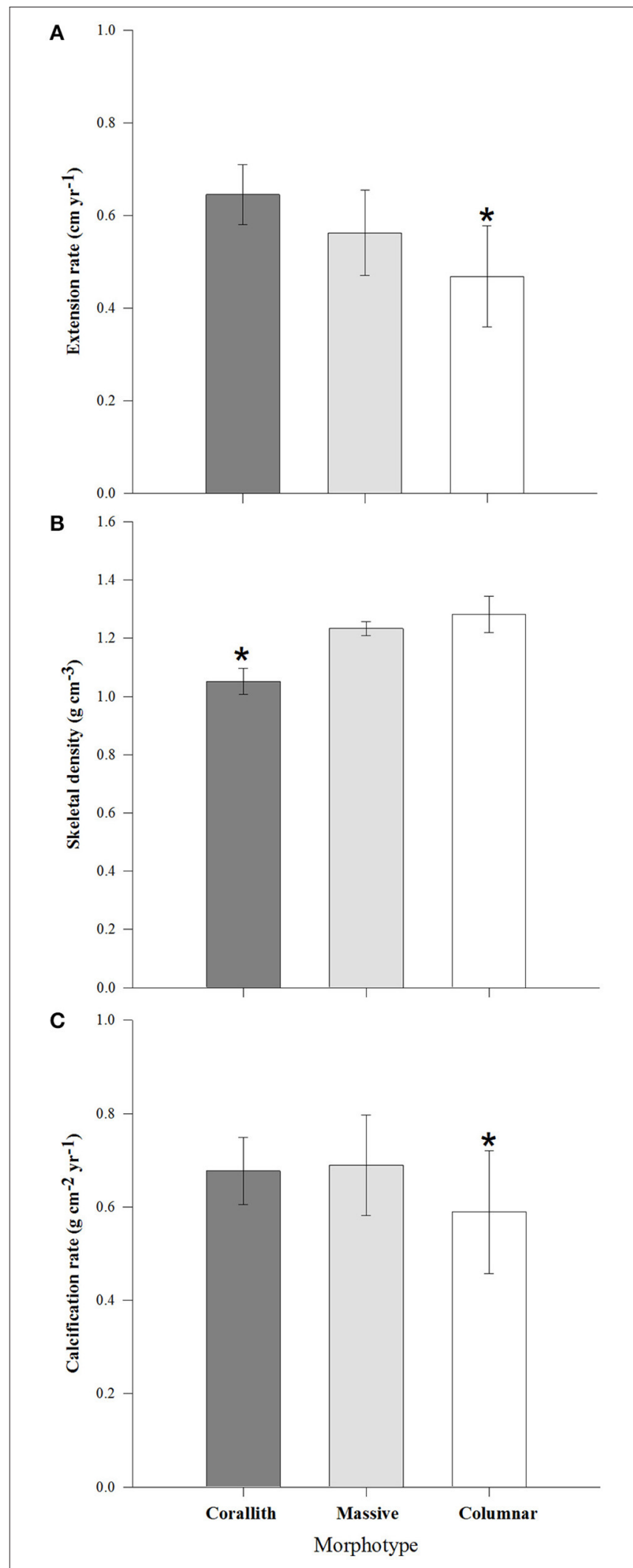

FIGURE 3 | Coral growth parameters ( $\pm 95 \%$ confidence limits)

comparison between morphotypes. (A) Extension rate, (B) Skeletal density, and $(\mathrm{C})$ Calcification rate. ${ }^{*}$ denotes statistically significant difference $(P<0.05)$.

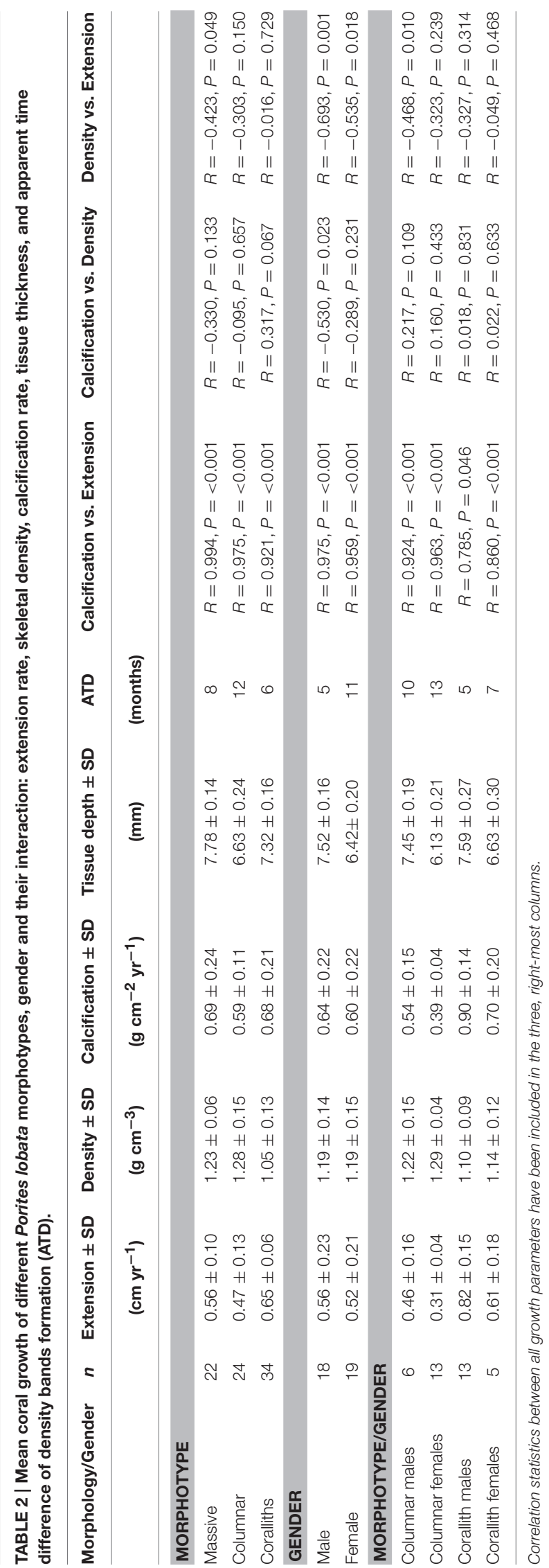


TABLE 3 | The results of two-way ANOVA's of Porites lobata in three coral growth parameters and the interaction of the gender using both columnar and corallith morphologies.

\begin{tabular}{llcccc}
\hline Parameter & Source & DF & MS & $\boldsymbol{F}$ & $\boldsymbol{P}$ \\
\hline Extension rate & Morphotype & 1 & 0.865 & 34.879 & $<\mathbf{0 . 0 0 1}$ \\
& Gender & 1 & 0.246 & 9.915 & $\mathbf{0 . 0 0 3}$ \\
& Morphotype $\times$ Gender & 1 & 0.006 & 0.226 & 0.637 \\
\hline \multirow{2}{*}{ Skeletal density } & Morphotype & 1 & 0.136 & 8.962 & $\mathbf{0 . 0 0 5}$ \\
& Gender & 1 & 0.0205 & 1.35 & 0.254 \\
& Morphotype $\times$ Gender & 1 & 0.002 & 0.098 & 0.756 \\
\hline \multirow{2}{*}{ Calcification rate } & Morphotype & 1 & 0.834 & 31.563 & $<\mathbf{0 . 0 0 1}$ \\
& Gender & 1 & 0.239 & 9.051 & $\mathbf{0 . 0 0 5}$ \\
& Morphotype $\times$ Gender & 1 & 0.005 & 0.191 & 0.665 \\
\hline
\end{tabular}

Bold values denotes statistically significant difference.

in extension and calcification rates $(P<0.01$; Table 3$)$, males colonies grew 30 and $40 \%$ faster than females for columnar and corallith morphologies, respectively (Figure 4). There was a positive relationship between extension and calcification rate $\left(r^{2}=0.889, P<0.001\right)$, but not between of skeletal density and calcification rate; in contrast, a weak relationship was found between extension rate and skeletal density $\left(r^{2}=-0.127, P=\right.$ 0.001 ). Similar pattern were revealed when relationships were analyzed by morphotypes (Table 2 ).

Tissue thickness averaged $6.63 \pm 0.14 \mathrm{~mm}$ for columnar growth forms, $7.78 \pm 0.13 \mathrm{~mm}$ for massive and $7.32 \pm 0.16 \mathrm{~mm}$ for coralliths, and these differences were statistically significant ( $H=24.895, P<0.001)$. There were gender differences of both columnar and corallith forms (Figure 5). The results reflects a 4-6 month differences in the apparent timing of density-band formation between morphotypes, this difference was displayed by the columnar forms with the lowest tissue thickness values compared to coralliths and massive (Table 2). In addition, a difference in the timing (months) of density-band formation among genders of $P$. lobata, with 5-month of difference for males, and 11 for females was observed. However, this was not consistent with the interaction effect between morphology and gender, where apparent timing of density- band formation was 2-3 month between genders in both columnar and corallith forms. These results indicate a stronger effect of the morphology with a 6-month difference in the apparent time of densityband formation between morphotype, even considering the colonies gender; where male and female coralliths showed faster extension, calcification rate, and thicker tissue compared with columnar colonies (Table 2).

\section{DISCUSSION}

Difference in calcification rate of distinct $P$. lobata morphotypes (Corallith, massive, and columnar) at the same depth range reveals the high plasticity of this scleractinian species and demonstrates that each morphotype grows at different rates, and such rates may depend on the colony's gender. Phenotypic plasticity has been reported for congeneric species in the central Pacific, which present different growth rates between distinct reef zones (e.g., high vs. low energy; Smith et al., 2007). Therefore, $P$. lobata appears to be able to readily modify their growth strategies, developing different forms and/or growing at different rates in order to persist over the reef framework.

All coral morphologies are distributed at the same depth range, but as expected, in different substrates. Columnar colonies of this study recruit to rocks and coral matrix, and is possible that they modify shapes depending of the complexity of the substrata and compete for space with other sessile species; when the available space is restricted coral growth could divert upward rather than sideward, promoting columnar forms (Van Veghel et al., 1996). Massive colonies were observed on calcareous platforms rounded by large sandy areas, a similar observation to that observed in the equatorial zone of the ETP (Guzmán, 1986). This particular shape allows the space separation $>1 \mathrm{~m}$, between colonies of the same form. It should be noted that massive growth forms tend to be larger and have higher in calcification rates compared with columnar and corallith forms. Therefore, massive forms are lesser extent by space and competition and may grow in both height and width, developing large colonies. The free-living (mobile) coralliths were found across flat, rocky areas between adjacent coral matrices. Then tended to develop rounded shapes due to interactions with coral reef fish and water energy. As the coralliths increase in diameter and weight, their morphology is ultimately subject to change over the time as they attach to the substrate (Glynn, 1974; Tortolero-Langarica et al., 2016).

The mean annual extension and calcification rates of $P$. lobata documented herein are the lowest (on average $\sim 2$-fold lower) documented for Porites genera across the Pacific Ocean (Guzmán and Cortés, 1989; Glynn et al., 1996; Lough et al., 1999; Lough and Barnes, 2000; Smith et al., 2007; Lough, 2008). Nevertheless, the range of extension values is similar to those of Porites species at the same latitude (Lough and Barnes, 2000). The upward growth and calcification rate of $P$. lobata corals from the eastern Pacific tend to decrease with increasing latitude, which is a similar pattern to that observed in massive Porites corals from the western Pacific (Lough and Barnes, 2000; Cooper et al., 2008). This may be influenced by the variability of the environment conditions at higher latitudes; for instance temperature and light decreases and higher nutrient load may inhibit or reduce coral growth, leading to lower extension, and calcification rates in corals of the sub-tropical latitudes of the ETP in comparison to conspecifics from tropical latitudes (Grigg, 1981; Risk and Sammarco, 1991; Lough and Barnes, 2000; Kessler, 2006; Pennington et al., 2006; Pantoja et al., 2012).

Differences in extension and calcification rates were observed between morphotypes, with columnar colonies presented the lowest rates compared with coralliths and massive (Table 2). Therefore, we reject the hypothesis that free-living coralliths may show slower rates compared with columnar and massive shapes. This may be explained because morphology forms of the same species can present different characteristics as a physiological response to intra-specific interactions for competition of habitat and resources (Van Veghel et al., 1996). These interactions 
A

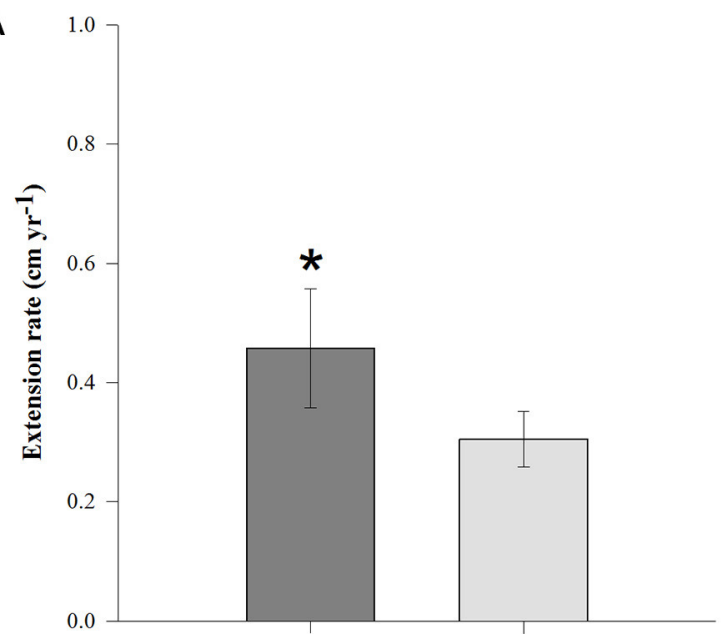

B

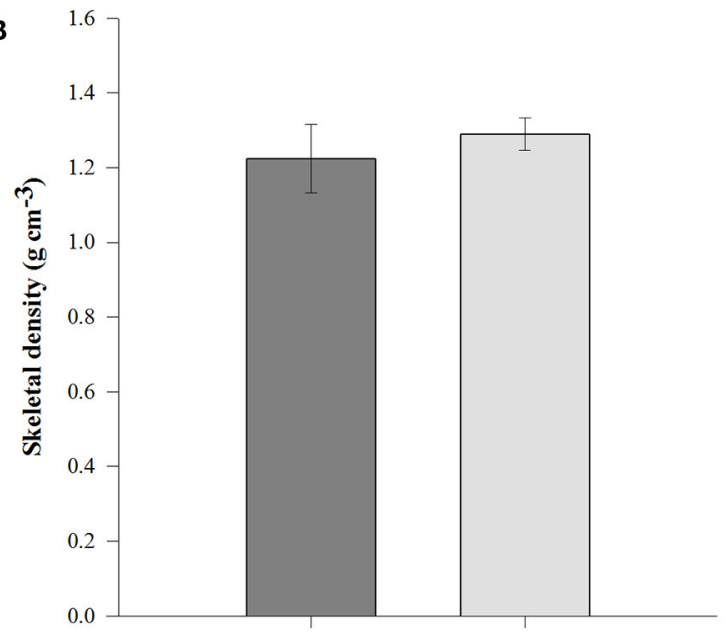

C

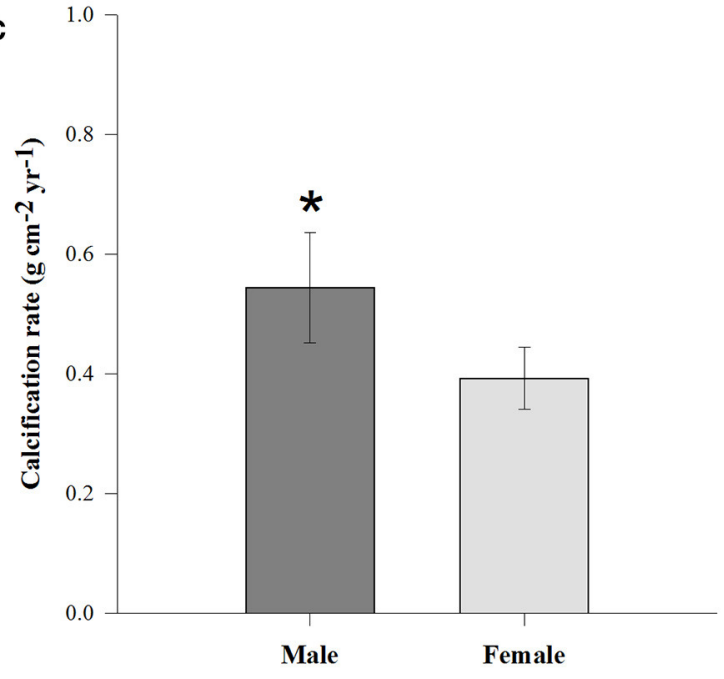

Columnar gender
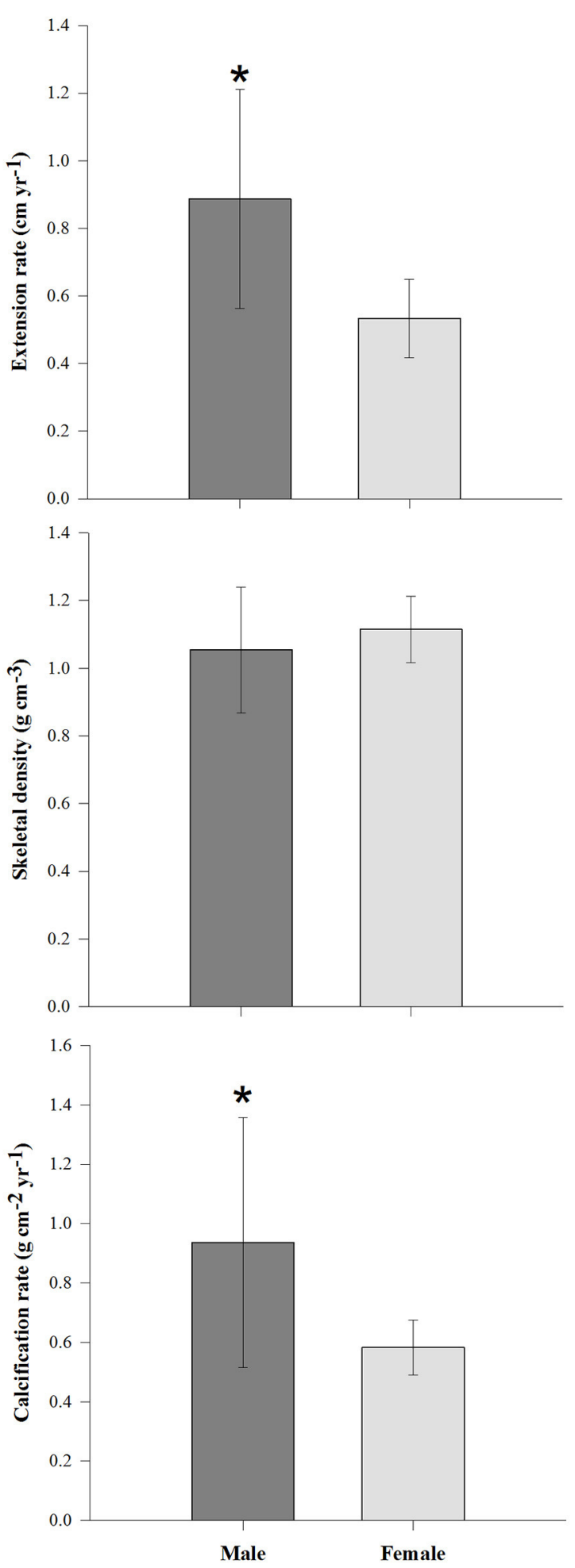

Corallith gender

FIGURE 4 | Growth parameters ( $\pm 95 \%$ confidence limits) of columnar and corallith morphotypes including the gender effect (differences between males and females). (A) Extension between males and females. (B) Skeletal density between male and females. (C) Calcification rate between male and females. *denotes statistically significant difference $(P<0.01)$. 


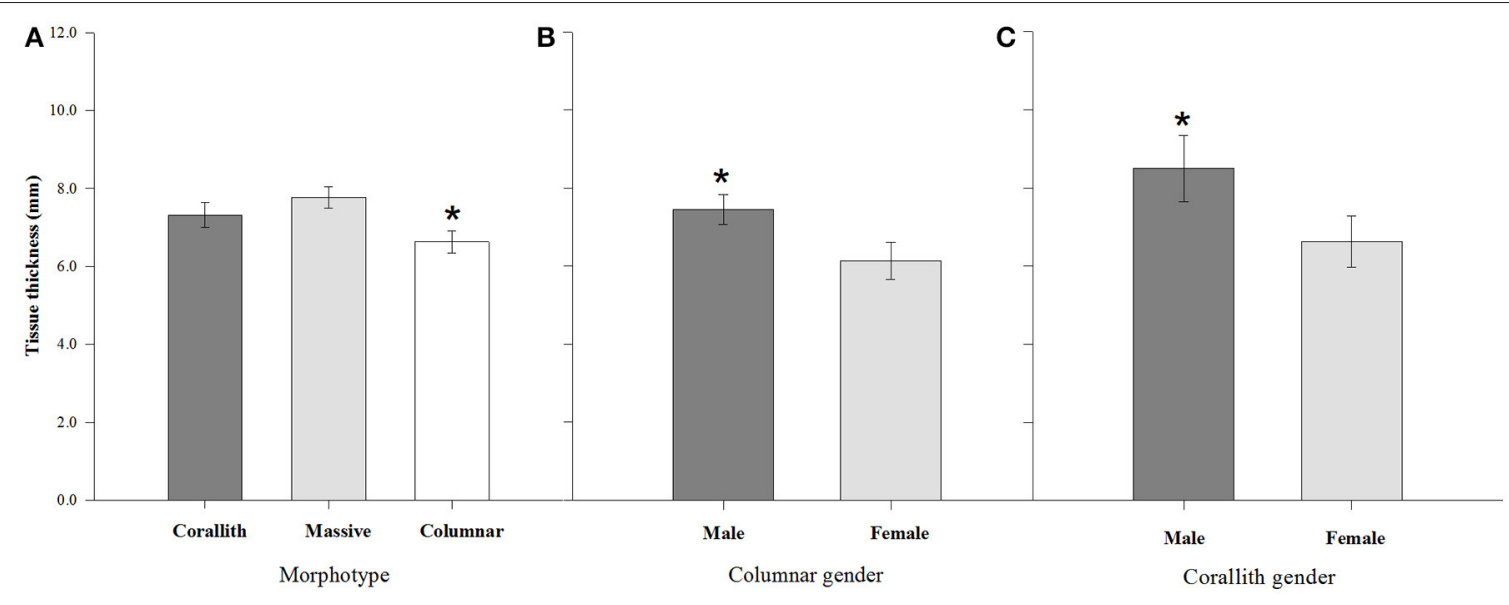

FIGURE 5 | Tissue thickness ( $\pm 95 \%$ confidence limits) differences among morphotypes and the effect of gender (across genders). (A) Comparison between corallith, massive and columnar morphologies. (B) Comparison between genders within the columnar morphotype group. (C) Comparison between genders within the corallith group. ${ }^{*}$ denotes statistically significant difference $(P<0.001)$.

may produce damage on coral tissue and erosion on the skeletal structure, generating a negative effect on extension and calcification rates (Carricart-Ganivet, 2007). Therefore, the organisms invest the energetic resources on tissue repair instead on growth.

In contrast with extension and calcification rates, skeletal density values of $P$. lobata are within the same range as those documented across the Pacific (Risk and Sammarco, 1991; Lough and Barnes, 2000; Carricart-Ganivet, 2007; Lough, 2008). At the population level, skeletal density is expected to be influenced by local environmental factors such as depth, nutrient load, sedimentation, light, water flux and $\mathrm{pH}$ (Grigg, 1982; Hughes, 1987; Risk and Sammarco, 1991; Lough and Barnes, 2000; Smith et al., 2007). Despite overall similarities in average levels with those documented in of the Pacific, differences between morphotypes were observed at IINP. Indeed, it is unsurprising that different morphologies' surface area/volume ratios could necessitate differences in density (Risk and Sammarco, 1991; Grigg, 2006; Smith et al., 2007; Lough and Cooper, 2011; Tortolero-Langarica et al., 2016).

Differences between genders were documented both herein and previously founded (Cabral-Tena et al., 2013; CarricartGanivet et al., 2013). Males in columnar and corallith morphotypes present higher growth rates than female colonies. On average, a coral colony invests $\sim 15 \%$ of its daily energy budget on reproduction (Sheppard et al., 2009), with a high energetic cost to produce eggs than sperm (Harrison, 1985). Brooding corals produces in asynchronic maturation many oocites per year (Rodríguez-Troncoso et al., 2011). Therefore, female colonies continuously invest energy during their reproductive periods reducing the amount of energy available for calcification (Harrison and Wallace, 1990). As $P$. lobata is characterized as a gonochoric brooder coral (Harrison, 2011), it seems likely that female colonies will decrease their growth to a greater extent than males during periods of the gametogenesis, thereby generating differences in calcification rates between genders (Figure 4). Also, this is confirmed by the differences in tissue thickness between genders (Figure 5), where males typically present a greater thickness than females (Carricart-Ganivet et al., 2013), and this is including herein for most morphotypes. Therefore, both gender and morphotype appear to affect the growth of P. lobata.

P. lobata showed a similar HD banded pattern between morphotypes during the summer season. However, results differed between morphotypes when apparent timing of density bands deposition was examined. The difference between actual and apparent HD banding is an average of 6 months. Herein $\mathrm{HD}$ bands begin to form during the late winter when the SST begins to increase gradually (Lough and Barnes, 2000). Then, they continue to form until the end of the summer season 6 months later. This is due to the porous nature Poritid skeletons, a characteristic that allows continuing depositing calcium carbonate under the tissue layer (Barnes and Lough, 1992, 1993; Carricart-Ganivet et al., 2013; Tortolero-Langarica et al., 2016).

This study has demonstrated difference in extension rate, skeletal density, and calcification rates between different $P$. lobata morphotypes and genders. P. lobata is highly phenotypically plastic (Smith et al., 2007) and is found in both the Eastern and Western Pacific, despite a barrier to gene flow across the Eastern Pacific Ocean (Baums et al., 2012). This widespread distribution suggests a marked ability to adapt or acclimatize to a wide variety of environment. Indeed, this characteristic helps to the species to maintain their distribution over the coral reef framework and serve as a framework building species in the reefs of the ETP region. In addition, the variability in growth parameters suggests that colony morphology may factor into local and regional comparison. This must be considered, for instance, because due morphological variation itself may mask growth difference between coral communities. Therefore, we recommended that, 
are growth comparisons to be made between localities or over the time, the same morphologies are compared against each other.

\section{AUTHOR CONTRIBUTIONS}

JT, AR, AC, JC have substantial contribution con the concept and design of the work, and also with the acquisition, analysis and interpretation of the data; JT, AR, JC, AM contribute with the draft of the word and revise the intellectual content; AR approve the final version of the manuscript. Finally, JT, AR, AC, JC, AM agree to be accountable for all aspects of the work in ensuring that questions related to the accuracy or integrity of the work are appropriately investigated and resolved.

\section{REFERENCES}

Alvarez-Filip, L., Dulvy, N. K., Gill, J. A., Coté, I. M., and Watkinson, A. R. (2009). Flattening of Caribbean coral reefs: region-wide declines in architectural complexity. Proc. R. Soc. Lond. B Biol. Sci. 276, 3019-3025. doi: 10.1098/rspb.2009.0339

Barnes, D. J., and Lough, J. M. (1992). Systematic variations in the depth of skeleton occupied by coral tissue in massive colonies of Porites from the Great Barrier Reef. J. Exp. Mar. Biol. Ecol. 159, 113-128. doi: 10.1016/0022-0981(92)90261-8

Barnes, D. J., and Lough, J. M. (1993). On the nature and causes of density banding in massive coral skeletons. J. Exp. Mar. Biol. Ecol. 167, 91-108. doi: 10.1016/0022-0981(93)90186-R

Barshis, D. J., Stillman, J. H., Gates, R. D., Toonen, R. J., Smith, L. W., and Birkeland, C. (2010). Protein expression and genetic structure of the coral Porites lobata in an environmentally extreme Samoan back reef: does host genotype limit phenotypic plasticity? Mol. Ecol. 19, 1705-1720. doi: 10.1111/j.1365-294X.2010.04574.X

Baums, I. B., Boulay, J. N., Polato, N. R., and Hellberg, M. E. (2012). No gene flow across the Eastern Pacific Barrier in the reef-building coral Porites lobata. Mol. Ecol. 21, 5418-5433. doi: 10.1111/j.1365-294X.2012.05733.x

Boulay, J. N., Cortes, J., Nivia-Ruiz, J., and Baums, I. B. (2012). High genotypic diversity of the reef-building coral Porites lobata (Scleractinia: Poritidae) in Isla del Coco National Park, Costa Rica. Rev. Biol. Trop. 60, 279-292.

Cabral-Tena, R. A., Reyes-Bonilla, H., Lluch-Cota, S., Paz-García, D. A., CalderónAguilera, L. E., Norzagaray-López, O., et al. (2013). Different calcification rates in males and females of the coral Porites panamensis in the Gulf of California. Mar. Ecol. Prog. Ser. 476, 1-8. doi: 10.3354/meps10269

Carricart-Ganivet, J. P. (2007). Annual density banding in massive coral skeletons: result of growth strategies to inhabit reefs with high microborers' activity? Mar. Biol. 153, 1-5. doi: 10.1007/s00227-007-0780-3

Carricart-Ganivet, J. P., and Barnes, D. J. (2007). Densitometry from digitized images of X-radiographs: methodology for measurement of coral skeletal density. J. Exp. Mar. Biol. Ecol. 344, 67-72. doi: 10.1016/j.jembe.2006. 12.018

Carricart-Ganivet, J. P., Vásquez-Bedoya, L. F., Cabanillas-Terán, N., and Blanchon, P. (2013). Gender-related differences in the apparent timing of skeletal density bands in the reef-building coral Siderastrea siderea. Coral Reefs 32, 769-777. doi: 10.1007/s00338-013-1028-y

Carriquiry, J. D., Cupul-Magaña, A., Rodríguez-Zaragoza, F., and Medina-Rosas, P. (2001). Coral bleaching and mortality in the Mexican Pacific during the 1997$98 \mathrm{El}$ Niño, and prediction from a remote sensing approach. Bull. Mar. Sci. 69, 237-249.

CONANP (2007). Programa de Conservación y Manejo del Parque Nacional Islas Marietas. México: Comisión Nacional de Áreas Naturales Protegidas.

Cooper, T. F., De'ath, A. G., Fabricius, K. E., and Lough, J. M. (2008). Declining coral calcification in massive Porites in two nearshore regions of the northern

\section{ACKNOWLEDGMENTS}

JT's work was supported by the doctoral fellowship CONACYT No. 262538. The present work was funded by the PROMEP project 220265 to $\mathrm{AR}$ and the projects P/PIFI-201014MSU0010Z-10 to AC, and PAPIIT IN209014 to JC. The authorities of Isla Isabel National Park (CONANP) are thanked for their assistance and use of facilities during the sampling and surveys periods, and thanks are also given to the "Instituto Tecnológico of Bahía de Banderas" for their help with field operations. Also the authors thank Dr. JL Carballo (UNAM ICMyL) for access to laboratory facilities and J Santiago-Valentín for the advice with the histological analysis. Finally, the authors would like to thank KL Kaiser for their valuable comments on the manuscript's English and scientific content.

Great Barrier Reef. Glob. Change Biol. 14, 529-538. doi: 10.1111/j.13652486.2007.01520.x

Cupul-Magaña, A., and Calderón-Aguilera, L. (2008). “Cold water bleaching at Islas Marietas National Park, Nayarit, México, Vol. 15,” in Congreso Nacional de Oceanografía (Veracruz).

D'Croz, L., Maté, J. L., and Oke, J. E. (2001). Responses to elevated sea water temperature and UV radiation in the coral Porites lobata from upwelling and non-upwelling environments on the Pacific coast of Panama. Bull. Mar. Sci. 69, 203-214.

da Silva, A. M., Young, C. C., and Levitus, S. (1994). Atlas of Surface Marine Data 1994, Vol. 4, Anomalies of Fresh Water Fluxes. NOAA Atlas NESDIS.

Duprey, N., Boucher, H., and Jiménez, C. (2012). Digital correction of computed X-radiographs for coral densitometry. J. Exp. Mar. Biol. Ecol. 438, 84-92. doi:10.1016/j.jembe.2012.09.007

Fiedler, P. C., and Talley, L. D. (2006). Hydrography of the eastern tropical Pacific: a review. Prog. Oceanogr. 69, 143-180. doi: 10.1016/j.pocean.2006.03.008

Forsman, Z. H., Barshis, D. J., Hunter, C. L., and Toonen, R. J. (2009). Shapeshifting corals: molecular markers show morphology is evolutionarily plastic in Porites. BMC Evol. Biol. 9:45. doi: 10.1186/1471-2148-9-45

Foster, A. B. (1979). Phenotypic plasticity in the reef corals Montastraea annularis (Ellis and Solander) and Siderastrea siderea (Ellis and Solander). J. Exp. Mar. Biol. Ecol. 39, 25-54.

Glynn, P. W. (1974). "Rolling stones among the Scleractinia: mobile coralliths in the Gulf of Panama," in Proceedings of the 2nd International Coral Reef Symposium, Great Barrier Reef Committee (Brisbane, QLD), 183-198.

Glynn, P. W. (1994). State of coral reefs in the Galápagos Islands: natural vs anthropogenic impacts. Mar. Poll. Bull. 29, 131-140.

Glynn, P. W. (2000). "Effects of the 1997-98 El Niño Southern-oscillation on Eastern Pacific corals and coral reefs: an overview," in Proceedings of the 9th International Coral Reefs Symposium (Bali), 169-1174.

Glynn, P. W., and Ault, J. S. (2000). A biogeographic analysis and review of the far eastern Pacific coral reef region. Coral Reefs 19, 1-23. doi: $10.1007 / \mathrm{s} 003380050220$

Glynn, P. W., Colley, S. B., and Eakin, C. M. (1994). Reef coral reproduction in the eastern Pacific: Costa Rica, Panamá, and Galápagos Islands (Ecuador). II. Poritidae. Mar. Biol. 118, 191-208. doi: 10.1007/BF00353270

Glynn, P. W., Veron, J., and Wellington, G. (1996). Clipperton Atoll (eastern Pacific): oceanography, geomorphology, reef-building coral ecology and biogeography. Coral Reefs 15, 71-100.

Graus, R. R., and MacIntyre, I. G. (1982). "Vanation in growth forms of the reef coral M. annulans (Ellis \& Solander): a quantitative evaluation of growth response to light distribution using computer simulation," in The Atlantic Barrier Reef Ecosystem at Carrie Bow Cay, Belize. I. Structure and Communities, eds K. Riitzler and I. G. MacIntyre (Washington, DC: Smithsonian Institution Press), 441-464. 
Grigg, R. W. (1981). "Coral reef development at high latitudes in Hawaii," in Proceedings of the 4th International Coral Reef Symposium, Vol. 1 (Manila) 687-693.

Grigg, R. W. (1982). Darwin point: a threshold for atoll formation. Coral Reefs 1, 29-34. doi: 10.1007/BF00286537

Grigg, R. W. (2006). Depth limit for reef building corals in the Au'au Channel, S. E. Hawaii. Coral Reefs 25, 77-84. doi: 10.1007/s00338-005-0073-6

Guzmán, H. M. (1986). Estructura de la Comunidad Arrecifal de la Isla del Cano, Costa Rica, y el Efecto de Perturbaciones Naturales Severas. Dissertation/master thesis, Universidad de Costa Rica, 179.

Guzmán, H. M., and Cortés, J. (1989). Growth rates of eight species of scleractinian corals in the eastern Pacific (Costa Rica). Bull. Mar. Sci. 44, 1186-1194.

Guzmán, H. M., and Cortés, J. (1993). Los arrecifes coralinos del Pacífico Oriental Ecuatorial: revisión y perspectivas. Rev. Biol. Trop. 41, 535-557.

Harrison, P. L. (1985). "Sexual characteristics of scleractinian corals: systematic and evolutionary implications," in Proceedings of the 5th International Coral Reef Symposium (Tahiti), 337-342.

Harrison, P. L. (2011). "Sexual reproduction of scleractinian corals," in Coral Reef: An Ecosystem in Transition, eds Z. Dubinsky and H. Stambler (New York, NY: EUA), 59-86.

Harrison, P. L., and Wallace, C. C. (1990). "Reproduction, dispersal and recruitment of scleractinian corals," in Ecosystems of the World: Coral Reefs, Vol. 25, ed Z. Dubinsky (Amsterdam: Elsevier), 133-207.

Hughes, T. P. (1987). Skeletal density and growth form of corals. Mar. Ecol. Prog. Ser. 35, 259-266.

Humanson, G. L. (1967). Animal Tissue Techniques. San Francisco, CA: W. H. Freeman and Company.

Kessler, W. S. (2006). The circulation of the Eastern tropical Pacific: a review. Prog. Oceanogr. 69, 181-217. doi: 10.1016/j.pocean.2006.03.009

Knutson, D. W., Buddemeier, R. W., and Smith, S. V. (1972). Coral chronometers: seasonal growth bands in reef corals. Science 177, 270-272.

López-Pérez, R. A. (2013). Species composition and morphologic variation of Porites in the Gulf of California. Coral Reefs 32, 867-878. doi: 10.1007/s00338013-1031-3

Lough, J. M. (2008). Coral calcification from skeletal records revisited. Mar. Ecol. Prog. Ser. 373, 257-264. doi: 10.3354/meps07398

Lough, J. M., and Barnes, D. J. (2000). Environmental controls on growth of the massive coral Porites. J. Exp. Mar. Biol. Ecol. 245, 225-243. doi: 10.1016/S00220981(99)00168-9

Lough, J. M., Barnes, D. J., Devereux, M. J., Tobin, B. J., and Tobin, S. (1999). Variability in Growth Characteristics of Massive Porites on the Great Barrier Reef. Technical Report No. 28, CRC Reef Research Centre, Townsville, QLD.

Lough, J. M., and Cooper, T. F. (2011). New insights from coral growth band studies in an era of rapid environmental change. Earth Sci. Rev. 108, 170-184. doi:10.1016/j.earscirev.2011.07.001

Muko, S., Kawasaki, K., Sakai, K., Takasu, F., and Shigesada, N. (2000). Morphological plasticity in the coral Porites sillimaniani and its adaptive significance. Bull. Mar. Sci. 66, 225-239.

Norzagaray-López, C. O., Calderon-Aguilera, L. E., Hernández-Ayón, J. M., ReyesBonilla, H., Carricart-Ganivet, J. P., Cabral-Tena, R. A., et al. (2014). Low calcification rates and calcium carbonate production in Porites panamensis at its northernmost geographic distribution. Mar. Ecol. 36, 1244-1255. doi: $10.1111 /$ maec. 12227

Palacios-Hernández, E., Carrillo, L. E., Filonov, A., Brito-Castillo, L., and CabreraRamos, C. E. (2010). Seasonality and anomalies of surface temperature off the coast of Nayarit, Mexico. Ocean Dyn. 60, 81-91. doi: 10.1007/s10236-0090244-z

Pantoja, D. A., Marinone, S. G., Parés-Sierra, A., and Gómez-Valdivia, F. (2012). Numerical modeling of seasonal and mesoscale hydrography and circulation in the Mexican Central Pacific. Cien. Mar. 38, 363-379. doi: $10.7773 / \mathrm{cm} . v 38 \mathrm{i} 2.2007$

Paz-García, D. A., Reyes-Bonilla, H., and Hernández-Cortés, M. P. (2009). Genetic Variation in Two Morphotypes of Porites panamensis from the Gulf of California, Mexico," in Proceedings of the 11th International Coral Reef Symposium (Fort Lauderdale, FL), 444-448.

Pennington, J. T., Mahoney, K. L., Kuwahara, V. S., Kolber, D. D., Calienes, R., and Chavez, F. P. (2006). Primary production in the Eastern tropical Pacific: a review. Progr. Oceanogr. 69, 285-317. doi: 10.1016/j.pocean.2006.03.012

Reyes-Bonilla, H., Carriquiry, J. D., Morales, G. E., and Cupul-Magaña, A. L. (2002). Effects of the 1997-99 El Niño and anti El Niño events on coral communities of the Pacific coast of México. Coral Reefs 21, 368-372.

Risk, M. J., and Sammarco, P. W. (1991). Cross-shelf trends in skeletal density of the massive coral Porites lobata from the Great Barrier Reef. Mar. Ecol. Prog. Ser. 69, 195-200.

Rodríguez-Troncoso, A. P., Carpizo-Ituarte, E., Leyte-Morales, G. E., ChiBarragán, G., and Tapia-Vázquez, O. (2011). Sexual reproduction of three coral species from the Mexican South Pacific. Mar. Biol. 158, 2673-2683. doi: 10.1007/s00227-011-1765-9

Shea, D. J., Trenberth, K. E., and Reynolds, R. W. (1992). A global monthly sea surface temperature climatology. J. Clim. 5, 987-1001.

Sheppard, C. R. C., Davy, S. K., and Pilling, G. M. (2009). The Biology of Coral Reefs. Londres: Oxford University Press.

Smith, L. W., Barshis, D. J., and Birkeland, C. (2007). Phenotypic plasticity for skeletal growth, density and calcification of Porites lobata in response to habitat type. Coral Reefs 26, 559-567. doi: 10.1007/s00338-007-0216-z

Spalding, M. D., Ravolius, C., and Green, E. P. (2001). World Atlas of Coral Reefs. UNEP/WCMC, University of California Press, EUA.

Todd, P. (2008). Morphological plasticity in scleractinian corals. Biol. Rev. 83, 315-337. doi: 10.1111/j.1469-185X.2008.00045.x

Tomascik, T. (1990). Growth rates of two morphotypes of Montastrea annularis along a eutrophication gradient, Barbados, W. I. Mar. Poll. Bull. 21, 316-381.

Tortolero-Langarica, J. J. A., Rodríguez-Troncoso, A. P., Carricart-Ganivet, J. P., and Cupul-Magaña, A. L. (2016). Skeletal extension, density and calcification rates of massive free-living coral Porites lobata Dana, 1846. J. Exp. Mar. Biol. Ecol. 478, 68-76. doi: 10.1016/j.jembe.2016.02.005

Van Veghel, M. L. J., and Bosscher, H. (1995). variation in linear growth and skeletal density within the polymorphic reef buildlng coral Montastrea annularis. Bull. Mar. Sci. 56, 902-908.

Van Veghel, M. L. J., Daniel, F. R., and Bak, R. P. M. (1996). Interspecific interactions and competitive ability of the polymorphic reef-building coral Montastraea annularis. Bull. Mar. Sci. 58, 708-803.

Veron, J. E. N. (2000). Corals of the World. Townsville, MC: Australian Institute of Marine Science.

Wang, C., and Fiedler, P. C. (2006). ENSO variability in the Eastern tropical Pacific: a review. Prog. Oceanogr. 69, 239-266. doi: 10.1016/j.pocean.2006.03.004

Conflict of Interest Statement: The authors declare that the research was conducted in the absence of any commercial or financial relationships that could be construed as a potential conflict of interest.

Copyright (c) 2016 Tortolero-Langarica, Cupul-Magaña, Carricart-Ganivet, Mayfield and Rodríguez-Troncoso. This is an open-access article distributed under the terms of the Creative Commons Attribution License (CC BY). The use, distribution or reproduction in other forums is permitted, provided the original author(s) or licensor are credited and that the original publication in this journal is cited, in accordance with accepted academic practice. No use, distribution or reproduction is permitted which does not comply with these terms. 